\title{
EL DUQUE DE RIVAS: DE LA EXALTACIÓN AL DESENGAÑO
}

\section{Armando LÓPEZ CASTRO}

\author{
Universidad de León
}

Hay estilos que se relacionan con una forma literaria, mientras otros tienen que ver más con una actitud o modo de ser. Uno de éstos fue el Romanticismo, que surge en los años finales del siglo XVIII como reacción a los excesos de los absolutismos y se identifica con el liberalismo socio-político de la revolución de 1789. Esta liberación sentimental, que adopta un tono filosófico en Alemania (La poesía es lo real absoluto, escribe Novalis en los Fragmentos), sensorial en Inglaterra (la Naturaleza me había impulsado hacia delante, señala Wordsworth en el Preludio) y retórico en Francia (El poeta sólo debe tomar consejo de la Naturaleza, de la verdad y de la inspiración, afirma Víctor Hugo en el prólogo de (romwell), se basa en el movimiento dialéctico de la conciencia, en el empuje del yo hacia la tensión idealizante del otro. Lo que diferencia al arte romántico, que busca su centro en la subjetividad, es que sentimentaliza la realidad (Sentimentalizar es ir más allá de lo real y de sus posibilidades, escribe Schiller en La educación estética del hombre). En España, desde el primer momento, hay también una relación clara entre romanticismo y política, pero la experiencia de 1808 hace que nuestro movimiento romántico tenga una raíz netamente nacional, adoptando dos modos o actitudes relacionadas: lo físico de nuestras tierras y lo espiritual de nuestra tradición. Ahora bien, en el fondo de todas estas modalidades late siempre el principio romántico del espíritu liberal, que constituye el nervio más profundo de nuestra modernidad.

Desde 1833, con el fin del absolutismo y el triunfo del liberalismo, hasta 1837, cuando la poesía romántica aparece ya plenamente consolidada, vienen a coincidir la pervivencia del clasicismo y la renovación romántica. La fecha límite es la de 1834, en la que se dan varios hechos significativos: la llamada de Espronceda, en su artículo Poesía, a un nuevo tipo de poesía política, que combine libertad y orden; la defensa de la inspiración por Jacinto Salas y Quiroga en el prólogo de sus Poesías; y la síntesis hecha por Alcalá Galiano, en el prólogo a El Moro Expósito del Duque de Rivas, de las nuevas modalidades poéticas, la histórica, la metafísica y la patriótica, destacando la necesidad de una poesía nacional y espontánea. Si a esto añadimos, en 1835, la publicación del artículo "El pastor Clasiquino", en el que Espronceda se burla de la separación de la poesía clasicista respecto de la realidad social, y la aparición de la revista El Artista (1835-1836), como órgano de expresión de los jóvenes románticos, nos damos cuenta de las contradicciones e inconsistencias del movimiento romántico. El caso de Rivas, con su cambio de tendencia política y literaria a partir de 1834, cuando vuelve a España por la amnistía de María Cristina y abandona su liberalismo juvenil por una posición más conservadora, al ser nombrado por Instúriz ministro de la gobernación en 1836, es un claro ejemplo de transición de la exaltación al desengaño, de lo elegíaco a lo satírico. Ante el desvanecimiento de sus ilusiones juveniles, se refugia en un patriotismo aristocratizante y tradicionalista, escribiendo en sus años finales nuevos romances históricos y obras dramáticas, que sirven de compensación a su 
abatido espíritu. Apartando su mirada del ingrato presente, vuelve sus ojos al pasado y lo revive con dolorosa melancolía ${ }^{1 .}$

Al comenzar el siglo XIX, el liberalismo progresista va siempre unido al Romanticismo. No hay que olvidar que el término liberal nace en Cádiz. En sus Orígenes del Liberalismo español, publicado en La América el 12 de junio de 1864, señala Alcalá Galiano: La voz liberal aplicada a un partido o a un individuo, es de fecha moderna y española en su origen, pues empezó a ser usada en Cádiz en 1811 y después ha pasado a Francia, a Inglaterra y a otros pueblos. En relación con ella surge la palabra romántico, que aparece por primera vez en el periódico madrileño Crónica Científica y Literaria, el 26 de junio de 1818, como resultado de la polémica, iniciada en 1814, entre el liberal José Joaquín de Mora, editor de Crónica, y el conservador Juan Nicolás Böhl de Faber, polémica que tuvo desde el principio un matiz político y que inició el debate sobre el romanticismo en España. Los críticos de la época fernandina, a excepción de Alcalá Galiano, se adhirieron al romanticismo histórico, en lugar del actual, con lo que se vino a potenciar el conservadurismo de sus orígenes en el contexto nacional de la Guerra de la Independencia y la Ominosa Década. En un momento tan arriesgado como el del sexenio absolutista (1814-1820), en el que lo fundamental era la renovación de la literatura nacional, importa más la continuidad que la ruptura. Para escritores de formación liberal como Martínez de la Rosa y el Duque de Rivas, que estuvieron presentes en las Cortes de Cádiz, se opusieron al régimen absolutista de Fernando VII y mantuvieron un contacto con otros romanticismos durante el exilio, el movimiento romántico no empieza ni acaba en un momento específico, sino que forma una evolución amplia y sostenida entre 1770 y 1870, cultivándose al lado del neoclasicismo, estableciendo la subjetividad como momento de la experiencia y manteniendo un diálogo entre el alma individual y la naturaleza universal. A pesar de sus altibajos, el romanticismo español se revela como un movimiento consciente de sus posibilidades, de la absoluta alteridad que se forma en el impulso de la tensión idealizante ${ }^{2}$.

Los primeros años de la vida de Ángel de Saavedra (1791-1865) aparecen marcados por la formación clásica en el Seminario de Nobles (1803-1806) de Madrid, adonde se había trasladado la familia en 1800, y la guerra de la Independencia (1808), que había creado un clima heroico y legendario. A pesar de la reacción absolutista de 1814, Rivas pudo desarrollar una intensa actividad política y literaria, según revelan sus discursos liberales, el leído en Córdoba en 1819 y el pronunciado en las Cortes el 9 de febrero de 1823, y la publicación en Cádiz de su primer libro de Poesías (1814), cuya edición, corregida y ampliada, apareció en Madrid en 1820. Dentro del clasicismo renacentista que preside ambas ediciones (En todas ellas he procurado imitar la sencillez en el modo de decir y de presentar los pensamientos que ostentan nuestros poetas del siglo XVI. Y aunque no me lisonjeo de haberlo conseguido, me contento sólo con haberlo inten-

\footnotetext{
${ }^{1}$ El movimiento romántico responde a distintas corrientes o tendencias, difíciles de reducir en una unidad, lo cual no impide que convivan en la escritura. A esta multiplicidad se ha referido G. Gusdorf en su estudio, Fondement du savoir romantique, París (Payot) 1982. Por lo que se refiere a la trayectoria de Rivas, V. Lloréns la ha sintetizado así: "La trayectoria del duque de Rivas es constante en su radicalismo, aunque invirtiendo los términos: el liberal exaltado de la juventud se ha convertido en el reaccionario también exaltado de la vejez", en El romanticismo español, Madrid (Castalia) 1979, p.166.

${ }^{2}$ Más que la rutinaria exposición histórica sobre el romanticismo, centrada en la polémica entre Böhl y Mora, es necesario fijarse en su carácter evolutivo a partir de la relación entre política y literatura, que es consustancial a nuestro siglo XIX. En este sentido, pueden verse, entre otros, los estudios de G. Carnero, Los orígenes del romanticismo reaccionario español: el matrimonio Böhl de Faber, Valencia (Facultad de Filología) 1978; y Russell P. Sebold, Trayectoria del romanticismo español, Barcelona, (Crítica) 1983.
} 
tado, afirma el autor en una Advertencia previa en la que declara cuál era su ideal estético), habría que destacar los poemas patrióticos, en los que adopta la disposición de la oda clásica, con su retórica y sus alusiones mitológicas, e imita a Quintana en su concepto liberal de la patria, y los poemas amorosos, que giran en su mayor parte en torno al personaje de Olimpia, a la que dedica 18 composiciones y donde la pasión vivida se va imponiendo a las convenciones de la primera colección. Al comparar las dos ediciones, observamos que la segunda, la de 1820, recoge lo mejor de la primera, como si tuviera la intención de superarla, volviendo a incluir el poema narrativo $E l$ paso honroso, pero en versión distinta a la primera, y las tragedias El Duque de Aquitania y Malek-Adhel, en las que se nota la sujección a los modelos clásicos. En las cantinelas, églogas, epístolas, letrillas, romances, odas y sonetos, géneros enumerados por el poeta, dominan los tópicos y la fraseología neoclásica, por lo que la originalidad hay que buscarla en las composiciones inspiradas por la misteriosa Olimpia, en las que bajo la retórica late el temblor de un sentimiento sincero. De todas ellas, ninguna tan expresiva como la elegía que comienza “Olimpia, ¿dónde estás?...En vano, en vano", en la que el poeta lamenta la ausencia de la amada y revive las etapas de su amor, según podemos ver en estos versos

Riberas del humilde Manzanares,
do la primera vez la viva lumbre
de sus ojos gocé; si visteis gratas
nacer esta pasión pura y eterna
en que me abraso mísero; si afables
visteis mi ardiente amor recompensado,
y a mi, felice de mi hermoso dueño
al lado encantador, de lindas flores
la frente orlada, y de festivo gozo
y de dulces placeres rodeado;
vedme ahora solo, y demudado y yerto
cual solitaria tórtola viuda,
que en lo repuesto de la oscura selva
llora su bien perdido, y mustia y sola
en la alta rama donde fue su dicha,
su arrullo esparce y su gemido al viento,
al débil rayo de menguante luna.
Ver trocados los plácidos cantares,
con que un tiempo solaz os di, en clamores
llorando ausente de mi Olimpia amada;
e invocar congojoso y despechado,
el agudo cuchillo de la muerte. (vv.93-115)

Desde el cuento narrativo hasta el canto lírico hay un largo proceso en el que se fueron refundiendo distintas formas de la tradición clásica. Una de ellas fue la elegía, que experimentó una gran transformación desde el período alejandrino hasta la poesía moderna. Lo que muestra la elegía latina, primera forma subjetiva de la literatura, es la representación autobiográfica. A partir de entonces, la elegía, asociada cada vez más al sentimiento de lo íntimo y de lo individual, adelgazará cada vez más sus con- 
tenidos narrativos y descriptivos, hasta el punto de constituirse como variante de la canción. Es lo que sucede con la elegía romántica, en la que el yo lírico de la experiencia es el principal protagonista. Por eso aquí, el desplazamiento de la felicidad del pasado ("de sus ojos gocé") a la soledad del presente ("vedme ahora solo"), la comparación ("cual solitaria tórtola viuda"), que nos lleva hasta el romance de Fontefrida, la caracterización adjetival ("gratas", "afables", "demudado y yerto", "mustia y sola", "congojoso y despechado") y el símbolo ("el agudo cuchillo de la muerte"), se asocian en un lenguaje íntimo y personal, donde la nota regionalista ("humilde Manzanares"), de luz y color ("la viva lumbre") y de velada sensualidad ("festivo gozo"), traslucen el apasionamiento del que lucha por expresarse a sí mismo. Aunque es visible la herencia de expresiones formularias, según revelan los adjetivos "mísero", "felice", "orlada" y "despechado", lo que cuenta es el deseo de hacerse oír con voz distinta, que deja superadas las convenciones amorosas de la primera colección ${ }^{3}$.

Desde el momento en que Ángel de Saavedra entra en el juego político, inducido por su amigo Alcalá Galiano ("arrastró a Saavedra en el torbellino de sus opiniones y en la carrera de su partido", recuerda Pastor Díaz), apoyando al grupo de los exaltados y votando a favor de la moción contra la soberanía de Fernando VII, comienza para él la etapa del exilio, que se prolonga desde 1823 a 1834 y supone una ampliación de sus horizontes literarios. Primero se refugia en Gibraltar, donde permanece hasta mayo de 1824. Después emprende el viaje a Inglaterra, en el que compone los poemas "Super flumina", "A las estrellas" y "El desterrado", que aparece publicado en los Ocios de Españoles Emigrados y ofrece algunas variaciones, sobre todo en ciertos pasajes políticos, respecto a la primera versión. Durante su estancia en Londres, publica "Cristóbal Colón" y "El sueño de un proscrito", y empieza la redacción del poema Florinda, basado en la leyenda de los amores del rey Rodrigo, que termina en la isla de Malta, donde escribe, entre 1827 y 1828, la tragedia Arias Gonzalo, la comedia Tanto vales cuanto tienes y el poema El faro de Malta, y comienza, en 1829, la redacción de su poema más ambicioso, El Moro Expósito o Córdoba y Burgos en el siglo X, que continúa en París en 1832 y no termina hasta mayo del año siguiente en Tours. De todas estas composiciones del destierro, que representan un claro avance en su camino hacia el romanticismo, habría que destacar tres poemas: A las estrellas, El faro de Malta y El Moro Expósito, pues en ellos se aprecia, de forma explícita, la fe del creador en un vacío o una ausencia, en la desnudez que hace posible la alteridad intrínseca a la existencia, el movimiento de la mediación tan propio del arte romántico. Ausencia o exilio de la voz que, tras un largo recorrido ("al cabo de largo tiempo", escribe Juan de la Cruz en el comentario a la canción XI del Cántico espiritual), viene a encontrar el centro mismo y la sola unidad de su sentido.

Aunque "El desterrado" tuvo una gran aceptación entre los emigrados españoles, debida al sentido político de crítica a la patria ingrata y a la ruptura con los modelos clasicistas, y “El sueño del proscrito” fue elogiado por Alcalá Galiano, que cerró con él su famoso discurso inaugural del Ateneo londinense, es sin duda el poema

\footnotetext{
${ }^{3}$ Para la cita de los poemas sigo la edición de las Obras completas, Madrid (Atlas) 1957, 3 vols., a cargo de J.Campos, preferible, a pesar de su erratas, a la de Aguilar (1956). En ella se alude al comentario del anónimo crítico, aparecido en El Espectador ( $\mathrm{n}^{\circ} 607,12$ diciembre 1822), en el que se hace una revisión de estos poemas primeros, que no han sido todavía suficientemente analizados. En cuanto a la elegía romántica, que incorpora las tradiciones bíblica y clásica, desprendiéndose cada vez más de ellas en la libre expresión de los sentimientos, tengo en cuenta el estudio de $\mathrm{M}^{\mathrm{a}}$. Paz Díez Taboada, La elegía romántica española, Madrid (CSIC) 1977, si bien la selección antológica no recoge las elegías dedicadas a Olimpia.
} 
A las estrellas, fechado "En el mar, 1824", el que ofrece una mayor intensidad del sentimiento y una expresión más desnuda

\section{A LAS ESTRELLAS}

¡Oh refulgentes astros!, cuya lumbre el manto oscuro de la noche esmalta y que en los altos cercos silenciosos giráis mudos y eternos;

y joh tú, lánguida luna!, que argentada las tinieblas presides, y los mares mueves a tu placer, $y$ ahora apacible señoreas el cielo;

¡ay, cuántas veces, ay, para mí gratas vuestro esplendor sagrado ha embellecido dulces felices horas de mi vida que a no tornar volaron!

¡Cuántas veces los pálidos reflejos de vuestros claros rostros derramados, húmedos resbalar por las colinas vi apacibles del Betis;

y en su puro cristal vuestra belleza reverberar con cándidos fulgores admiré al lado de mi prenda amada, más que vosotros bella!
Ahora al brillar en las salobres ondas solo y mísero, prófugo y errante, de todo bien me contempláis desnudo, y a compasión os muevo.

¡Ay! Ahora mismo vuestras luces claras que el mar repite y reverente adoro, se derraman también sobre el retiro, donde mi bien me llora.

Tal vez en este instante sus divinos ojos clava en vosotros, joh, lucientes astros!, y os pide, con lloroso ruego, que no alteréis los mares.

$Y$ el trémulo esplendor de vuestras lumbres en las preciosas lágrimas riela, que esmaltan, jay!, sus pálidas mejillas, y más bella la tornan.

Al principio fue la experiencia vivida, después su evocación. De las dos partes en que se divide el poema, marcadas por el límite del adverbio temporal ("Ahora"), mientras las cinco primeras estrofas (vv.1-20), envueltas por la exclamación (“iOh refulgentes astros!") y la anáfora ("cuántas veces"), intensifican un mismo clima afectivo de lejana felicidad en el recuerdo, las cuatro últimas (vv.21-36), al proyectar la ausencia del amor ("mi prenda amada") sobre la desolación presente ("solo y mísero, prófugo y errante"), abren dicha experiencia a la posibilidad de la creación. Porque el poeta sabe que todo lo que fue antes puede volver a ser en el instante de la palabra ("Ahora"), que nos rescata del infierno de la división. De ahí que la repetida invocación a los astros (“¡Oh refulgentes astros!”, “¡oh, lucientes astros!”), desde el desgarro de la lejanía ("con lloroso ruego"), a la que se une el paisaje romántico de la luna (“¡oh tú, lánguida luna!"), tiene por objeto conjurar la separación de la amada. La contemplación de los astros en medio de la noche, diosa originaria ("En el principio era la noche", confirma el comienzo de la cosmogonía órfica), da paso al instante creador, que acoge la fecundidad de lo ausente. Dado que el viaje poético es de ida y vuelta, el hablante desciende aquí para ascender, para recobrar el pasado ("dulces horas de mi vida"), proyectarlo sobre el presente de la separación ("donde mi bien os llora") y hacerlo más verdadero en el recuerdo ("más bella la tornan"). El poeta no busca se- 
parar, sino unir, por eso el reflejo de los astros sobre el mar traduce lo imposible como deseo, la reunión del amor perdido ${ }^{4}$.

El Duque de Rivas intentó pasar de Londres a Italia, deteniéndose unos meses en Gibraltar, donde casó con doña Encarnación Cueto y Ortega, hermana de Leopoldo Cueto, marqués de Valmar, pero al intentar desembarcar en Liorna, las autoridades pontificias se lo prohibieron, por lo que se estableció en Malta gracias al pasaporte del cónsul inglés John Hoockham Frere, admirador de España y que influyó en su orientación romántica. Allí permaneció desde 1825 hasta 1830, en que marchó a París, y en el clima apacible de la isla comenzó a escribir El Moro Expósito y los primeros Romances históricos. Al poco tiempo de llegar a la isla, compuso "El faro de Malta", que es tanto un homenaje a la hospitalidad de la isla, simbolizada en su faro, como una evocación nostálgica de la patria desde el destierro:

\section{EL FARO DE MALTA}

Envuelve al mundo extenso triste noche, ronco huracán y borrascosas nubes confunden y tinieblas impalpables

4 el cielo, el mar, la tierra.

Y tú invisible te alzas, en tu frente ostentando del fuego una corona, cual rey del caos, que refleja y arde

8 con luz de paz y vida.

En vano ronco el mar alza sus montes y revienta a tus pies, do rebramante creciendo en blanca espuma, esconde y borra

12 el abrigo del puerto.

Tú, con lengua de fuego, "Aquí está", dices, sin voz hablando al tímido piloto, que como a numen bienhechor te adora,

16 y en ti los ojos clava.

Tiende apacible noche el manto rico que céfiro amoroso desenrrolla, recamado de estrellas y lucero,

20 por él rueda la luna.

Y entonces tú, de niebla vaporosa vestido, dejas ver en formas vagas tu cuerpo colosal, y tu diadema

24 arde al par de los astros.
Duerme tranquilo el mar, pérfido esconde rocas aleves, áridos escollos: falso sueño son, lejanas cumbres 28 engañan a las naves.

Mas tú, cuyo esplendor todo lo ofusca, tú, cuya inmoble posición indica el trono de un monarca, eres su norte, 32 les adviertes su engaño.

Así de la razón arde la antorcha, en medio del furor de las pasiones $o$ de aleves halagos de fortuna,

36 a los ojos del alma.

Desque refugio de la airada suerte en esta escasa tierra que presides, y grato albergue el cielo bondadoso 40 me concedió propicio,

ni una vez sólo a mis pesares busco dulce olvido del sueño entre los brazos sin saludarte, $y$ sin tornar los ojos

44 a tu espléndida frente.

¡Cuántos, ay, desde el seno de los mares al par los tornarán!...Tras larga ausencia unos que vuelven a su patria amada,

48 a sus hijos y esposa.

\footnotetext{
${ }^{4}$ En su artículo "Don Ángel de Saavedra, Duque de Rivas", fechado en Madrid en 1889, al referirse al exilio del escritor, afirma Juan Valera: "un período completo y distinto de la vida literaria de España en el siglo XIX: el período de la emigración”, en Obras, Madrid (Aguilar) Tomo II, 1942, p.724. Para esta etapa fundamental de la emigración, es necesario tener en cuenta las obras de A.Alcalá Galiano, Literatura española del siglo XIX. De Moratín a Rivas, con traducción, introducción y notas de V.Lloréns, Madrid, Alianza, 1969; y del propio V.Lloréns, Liberales y románticos. Una emigración española en Inglaterra (1823-1834), $3^{\mathrm{a}}$ ed., Madrid (Castalia) 1979, pp.207-214.
} 
Otros prófugos, pobres, perseguidos, que asilo buscan, cual busqué, lejano, y a quienes que lo hallaron, tu luz dice,

52 hospitalaria estrella.

Arde y sirve de norte a los bajeles, que de mi patria, aunque de tarde en tarde me traen nuevas amargas, y renglones

56 con lágrimas escritos.

Cuando la vez primera deslumbraste mis afligidos ojos, jcuál mi pecho, destrozado y hundido en la amargura,

60 palpitó venturoso!

Del Lacio moribundo las riberas huyendo inhospitales, contrastando del viento y mar entre ásperos bajíos 64 vi tu lumbre divina; viéronla como yo los marineros, $y$, olvidando los votos y plegarias que en las sordas tinieblas se perdian,

68 “Malta!! ¡iMalta!!, gritaron;

y fuiste a nuestros ojos la aureola que orna la frente de la santa imagen en quien busca afanoso el peregrino

72 la salud y el consuelo.

Jamás te olvidaré, jamás...Tan sólo trocara tu esplendor, sin olvidarlo, rey de la noche, y de la excelsa cumbre

76 la benéfica llama,

por la llama y los fúlgidos destellos que lanza, reflejando al sol naciente, el arcángel dorado que corona

80 de Córdoba la torre.

El poeta romántico se siente exiliado de un mundo perdido, la infancia o la patria, y esta conciencia de pérdida tiñe de melancolía el momento presente. Por eso aquí, la contemplación del faro, símbolo de iluminación y de la claridad del espíritu, permite al hablante diferenciarse del presente y volver al pasado, vivir lo posible como real. Allí donde va y viene el mar, imagen transparente de la memoria, da forma humana a los recuerdos perdidos. Mirar el faro para poder verse a sí mismo, para sentirse otro distinto del que se es. Mientras lo presente es siempre insatisfactorio, en lo lejano, en lo perdido, está la verdadera felicidad. De ahí que en este amplio poema, como es propio de los escritores españoles pertenecientes a la primera generación romántica, bajo el molde de la retórica neoclásica, visible tanto en la ordenación de la estrofa sáfica como en el sentido de la composición, pues el adverbio del v.33 ("Así") funciona como límite que nos hace pasar de lo concreto al mundo moral, late una nueva orientación romántica, comunicada al lector mediante un lenguaje afectivo, donde el uso de la prosopopeya o personificación ("Y tú", "Y entonces tú", "Mas tú"); de adjetivos antepuestos con valor determinativo ("triste noche", "falso sueño", "airada suerte", "dulce olvido", "hospitalaria estrella", "afligidos ojos", "sordas tinieblas"), que ponen de relieve una cualidad escogida por el hablante; el manejo del contraste, tan propio de la estética romántica, entre movilidad y estatismo, sombras y luz, caos y orden; y el complejo simbólico, dominado por el mar, al que se asocian la noche, la luna, el sueño y la llama, revelan todos ellos una proyección sentimental donde la evocación nostálgica de la tierra, plasmada por la imagen final de la veleta, en forma de ángel dorado, que corona la catedral de Córdoba, descubre la conciencia de escisión entre la Naturaleza y el hombre, que atormenta al artista romántico. En el sentimiento de escisión que domina el poema, donde la separación y el deseo de retorno resultan inseparables dentro del paisaje nocturno, encontramos la clave de esta nueva sensibilidad romántica. El faro, con su luz en la noche, espacio sin límites, es una contemplación que permite percibir la imagen integral de la nostalgia 1

\footnotetext{
${ }^{1}$ Convirtiendo al faro de Malta en símbolo de la razón ilustrada, afirma J.Casalduero: "No se trata de una alegoría, sino de
} 
El exilio deja al hombre a la intemperie, fuera de los límites, en presencia de su propia posibilidad. Más que un espacio físico, el exilio aparece como estado de escritura, de espera o de escucha, del que comparece ante la palabra. A ese momento de ausencia e inminencia, de abandono de lo vivido y de apertura hacia lo que todavía no ha llegado a manifestarse, pertenece El Moro Expósito (1834), poema escrito entre septiembre de 1829 y mayo de 1833, que corresponde a la plenitud de la trayectoria creadora de Rivas y representa el inicio de la poesía romántica en España, anticipándose al propio Don Álvaro (1835). Dejando aparte el problema ya estudiado de sus fuentes documentales y literarias, vamos a centrarnos en el motivo del reconocimiento, que estructura y da sentido a esta narración poética. Por eso, de las dos partes en que se divide la obra, una primera, cuya acción principal se desarrolla en Córdoba, comprendiendo los cinco primeros romances, y una segunda, que se desarrolla en el condado de Castilla y abarca los siete restantes, es esta última la que destaca por su mayor sobriedad y dramatismo, como podemos ver en el Romance séptimo, donde el señor de Lara, ya anciano y ciego, es capaz de reconocer a su hijo ignorado hasta entonces:

\author{
Dijo el anciano; enmudecido, Zaide \\ en sus trémulos brazos arrojóse; \\ Nuño, con gran cariño, de Mudarra \\ besó la ardiente faz. El sacerdote, \\ al artesón las palmas levantando, \\ en un tedéum prorrumpió, y al joven \\ cercando los hidalgos y escuderos, \\ hincada una rodilla, en altas voces \\ le rinden de lealtad el homenaje, \\ $y$ futuro señor le reconocen \\ del estado de Salas; ofreciendo \\ la antigua estancia, a media luz entonces, \\ un cuadro digno de que el gran Velázquez, \\ gloria de los pinceles españoles, \\ o el insigne Rembrandt, ejercitaran \\ en él su ingenio y mágicos colores. \\ Referir del anciano y ciego Lara \\ las palabras y varias sensaciones, \\ al recibir el misterioso anillo, \\ que el discreto mancebo presentóle,
}

reconociendo al punto con el tacto sus combinadas piedras y labores, y contar el horror, pasmo y asombro que muestra, cuando a Zaide contar oye

del tirano Giafar la horrenda muerte, primera hazaña del mancebo noble, y su llanto pintar y desconsuelo al escuchar, pues fue terrible golpe

para su corazón, que no existía el astro de sus últimos amores; y repetir de Zaide y de Salido los recuerdos, preguntas e ilusiones;

y del docto arcipreste las arengas; de las dueñas y antiguos servidores del palacio el contento y esperanzas; y las patrañas necias y discordes

que en Salas discurrieron aquel día, fuera perderse en intrincados montes y navegar un piélago insondable sin hallar puerto ni encontrar el Norte.

\footnotetext{
una natural trasposición. El cuadro real, pero compuesto para abarcar los dos estados esenciales de la noche con doble función esencial del faro (guiar, advertir), está visto y formado con sensibilidad y sentimiento dieciochescos y es el siglo XVIII quien impone ese significado a la luz, luz mental y moral, no la luz sobrenatural y metafísica del Barroco, ni la luz material del siglo XIX a partir del Romanticismo", de su ensayo "El destierro vivificador del estro poético: El faro de Malta", en Estudios de literatura española, $3^{\text {a }}$ ed., Madrid (Gredos) 1973, p.192. Y sin embargo, elementos como el ambiente nocturno, el predominio de lo sentimental y la evocación nostálgica de la patria confirman un mayor acercamiento a la nueva sensibilidad romántica. En cuanto a la conciencia de la escisión que revela el paisaje romántico, véase el estudio de R. Argullol, La atracción del abismo, Barcelona (Plaza y Janés) 1987.
} 
El arte no es otra cosa que un lenguaje del re-conocimiento. No es casual que, en este fragmento, que podría figurar como síntesis del todo el poema, pues en él resaltan como aspectos básicos la caracterización de los personajes, la forma novelesca de la narración y los contrastes entre lo trágico y lo cómico, sea precisamente el reconocimiento del hijo ausente por el padre anciano, al recibir éste "el misterioso anillo", el que ocupa el centro del cuadro, ya que el reconocimiento, en el que se hace visible lo permanente, lo esencial, y la familiaridad con el mundo, forma parte del lenguaje simbólico. Si en su significado originario el símbolo es algo en lo que se conoce y reconoce algo, ese anillo, que Zahira da a Mudarra al morir y que aparece en los Romances I, III, IV y VII, apunta a una relación originaria, a una no-distinción estética obtenida por una transformación, que constituye la experiencia propia del arte romántico. Porque Mudarra, de cuyo origen nada sabemos y sobre el que pesa una oscura herencia, es un héroe romántico que se debate entre el presente y el pasado, mostrando la conexión entre leyenda e historia, realidad e imaginación, dentro del sentido providencialista que preside la obra. Su imaginación "rica y ardiente" (VII, 437), que traduce la del poeta, da un ritmo dinámico a la narración, conseguido mediante los contrastes, los encabalgamientos, la abundancia de formas verbales simples y la acumulación de detalles en las escenas costumbristas, que hacen que la atención del lector discurra entre lo real y lo sobrenatural, dispuesta siempre a captar sus matices simbólicos. Esta capacidad transformadora de la imaginación artística, a la que se refiere Alcalá Galiano al final de su prólogo ("El poeta ha querido empeñar la curiosidad del lector, acomodar su estilo al argumento y adaptarlo a las personas que hablan; dibujar y colorear sus cuadros tal como él los concibe; describir objetos que son, fueron o pueden ser reales; conservar aun en lo ideal las facciones naturales que dan a las cosas imaginarias apariencia de ciertas. Y, por último, seguir los impulsos propios, obedecer las inspiraciones espontáneas y hacer no lo que han hecho, sino del modo que lo han hecho los célebres ingenios extranjeros del presente"), prólogo que no despertó el interés deseado, desborda lo que es y se manifiesta como posibilidad ("describir objetos que son, fueron o pueden ser reales"), como esperanza de ser. La realidad es lo que es, pero también puede ser algo distinto, y en lo posible imaginado se refleja el verdadero ser de la experiencia artística².

Si El Moro Expósito supone la ruptura definitiva con la preceptiva neoclásica desde el punto de vista poético, el estreno de Don Álvaro en el teatro del Príncipe el 22 de marzo de 1835, equiparable al de Hernani de Víctor Hugo en 1830, que el propio Rivas presenció en París, nos ofrece la clave de la sensibilidad romántica, que si sorprendió entonces por su carácter subversivo fue sin duda por la relación que se establece entre su significado, la fuerza del destino que va destruyendo gradualmente al protagonista, y la preocupación por la escenografía, que mantiene en juego lo histórico, lo pictórico y lo musical, conciencia que no hallamos en los otros dramaturgos de la época, salvo en Zorrilla. En realidad, y esto sucede en todas las épocas, nuevas ideas exigen nuevos modos de expresión ("Pues la época es nueva, nuevos los inter-

\footnotetext{
${ }^{2}$ Sobre el análisis del poema se pueden citar, entre otros, los estudios de E.A.Peers, "The Moro expósito and Spanish Romanticism", en Studies in Philology, 19, Chapel Hill, 1922; G.Boussagol, Angel de Saavedra, Duc de Rivas. Sa vie, son oeuvre poétique, Toulouse (E. Privat) 1926; R. Ménéndez Pidal, La epopeya castellana a través de la literatura española, $2^{\mathrm{a}}$ ed., Madrid (Espasa Calpe) 1959; y V. Lloréns, El Romanticismo español, opus cit., pp.128-149. Por lo que se refiere al sentido providencialista del poema, el mejor estudio sigue siendo en de A. Crespo, Aspectos estructurales de El moro expósito del Duque de Rivas, Uppsala (Acta Universitatis Upsaliensis) 1973.
} 
eses, nuevas las instituciones y todo en suma nuevo, debía serlo igualmente el dra$m a^{\prime \prime}$, afirma Alcalá Galiano en el Semanario Pintoresco en 1838), de manera que lo nuevo es la consideración del destino como fuerza caprichosa, a medio camino entre la fatalidad pagana y la Providencia cristiana, y de la obra dramática como síntesis de elementos dispares. Un ejemplo de esa integración entre la fuerza del destino, que actúa con trágica ironía, y el virtuosismo técnico se da en la escena III de la Jornada II, la más larga y simbólica, donde Leonor aparece intentando buscar refugio en la religión, en medio de un paisaje abrupto que refleja su estado de ánimo

\section{(Se sienta mirando en rededor y luego al cielo)}

\author{
¡Qué asperezas! ¡Qué hermosa y clara luna! \\ ¡La misma que hace un año \\ vió la mudanza atroz de mi fortuna \\ y abrirse los infiernos en mi daño! \\ (Pausa larga)
}

No fue ilusión...Aquel que de mí hablaba

dijo que navegaba

don Álvaro, buscando nuevamente

los apartados climas de Occidente.

¡Oh Dios! ¿Y será cierto?

Con bien arribe de su patria al puerto.

(Pausa)

\author{
¿Y no murió la noche desastrada \\ en que yo, yo..., manchada \\ con la sangre infeliz del padre mío, \\ le segui, le perdí?...¿ Y huye el impío? \\ ¿Y huye el ingrato? ¿Y huye y me abandona? \\ (Cae de rodillas)
}

\author{
¡Oh, Madre Santa de piedad!, perdona, \\ perdona, le olvidé. Si, es verdadera, \\ lo es mi resolución. Dios de bondades, \\ con penitencia austera, \\ lejos del mundo en estas soledades, \\ el furor expiaré de mis pasiones. \\ Piedad, piedad, Señor, no me abandones.
}

Esta escena, que se mueve de la culpa al perdón, muestra la preocupación romántica de hallar un sentido a la vida. Las marcas subjetivas de la exclamación y la interrogación, los puntos suspensivos con su gran volumen de sugerencia, el valor determinativo de los adjetivos ("la mudanza atroz de mi fortuna", "la noche desastra$d a "$, "la sangre infeliz del padre mío") y el símbolo de la luna, unido a la inconstancia del destino, al que hay que añadir el de la cruz que aparece en la acotación escénica ("En medio de la escena habrá una gran cruz de piedra tosca y corroída por el tiempo, puesta sobre cuatro gradas que pueden servir de asiento"), en clara alusión a la conjunción de contrarios como base de la existencia humana, ponen de relieve la exaltación emocional de Leonor, la cual, víctima del destino adverso, de la muerte de su padre y del abandono de don Álvaro, busca auxilio en el convento de los Ángeles. El lenguaje dramático, con su simbolismo religioso, revela una evolución de la esperanza a la desesperanza, que la divina Providencia no puede contrarrestar la fuerza del destino, lo cual viene confirmado por la angustiosa pregunta de don Álvaro en la escena VI de la Jornada V (“¡Oh Dios! ¿Me rehúsa vuestra gracia sus auxilios?”), cuya interrogación retórica, de tan acusada presencia en la obra, viene a confirmar el abismo entre Dios y el hombre, cumpliéndose así la predicción inicial de Preciosilla en la Jornada I: "Hace pocos días que le dije la buenaventura (y por cierto no es buena la que le espera si las rayas de la mano no mienten), y me dio una onza de oro como un sol de mediodía". Cuando se cumple el destino adverso ("Negra suerte le espera", dice la gitana respecto de Leonor), desaparece el último soporte existencial y al héroe romántico no le queda otra salida que la muerte. Lo importante de tales decisiones, 
como la de Leonor cuando se "abraza con la cruz" con la firme determinación de no abandonar el lugar o la de don Álvaro cuando expresa su amargo desengaño como un clamor en "el desierto", es que aparecen vistas en escena, como un juego entre el actor y la decoración ${ }^{3}$.

Si la literatura es el reflejo de la sociedad en la que surge, los intentos por imitar las formas convencionales de la literatura neoclásica, según revela la escritura épica de Lista en el inconcluso Pelayo, no fueron sino anacronismos y desenfoques. Precisamente la confluencia de narratividad y lirismo, producto de la desaparición de los límites entre los géneros clásicos, y el desarrollo del espíritu nacional, de acuerdo con la teoría herderiana del Volk geist, hicieron posible la aparición de dos formas narrativas, la leyenda y el romance, sobre todo este último, forma tradicional de la poesía castellana, que había sufrido un notable descrédito durante la Ilustración. Las recopilaciones romancísticas de los filólogos alemanes Grimm, Diez y Depping, seguidas por las traducciones de los hispanistas ingleses y franceses, Rodd, Bowring, Lockhart y Abel Hugo, se vieron continuadas entre nosotros por la primera Colección de romances clásicos de Agustín Durán, publicada en cuatro tomos entre 1828 y 1832, el Romencero (1834), de Manuel María del Mármol, y los Romances históricos (1841), del Duque de Rivas, que suponen una restauración del romance como forma poética moderna.

En el extenso prólogo de Rivas, que es tanto una apología del romance en contra de la preceptiva neoclásica (el romance octosilábico castellano es acaso la combinación métrica que, obteniendo la primacía para la poesía histórica, como la más apta para la narración y la descripción, se presta más naturalmente a todo género de asuntos, a toda especie de composiciones) como una exposición de su propósito al escribirlos (Volverlo a su primer objeto y a su primitivo vigor y enérgica sencillez, sin olvidar los adelantos del lenguaje, del gusto de la filosofía, y aprovechándose de todos los atavios con que nuestros buenos ingenios lo han engalanado), observamos un alejamiento de la elocuencia histórica, que aún domina en El Moro Expósito, y una mayor proximidad a la imaginación fundada en el sentimiento (Por fortuna, el ingenio creador y la imaginación fecunda producen sus grandes bellezas sin acordarse de los preceptistas y echando mano del instrumento que su propio instinto les sugiere como el más a propósito en el momento de la inspiración), de modo que, en los mejores de ellos, como "El alcázar de Sevilla", "Don Álvaro de Luna", "Un castellanano leal" y "Una noche de Madrid de 1578", se dan las mismas cualidades de argumentos hábilmente conducidos, estructura dramática, caracteres marcados y lenguaje castizo. De todos ellos, tal vez sea "Un castellano leal", que narra la decisión del conde de Benavente de incendiar su palacio de Toledo por haber vivido en él unos días el duque de Borbón por orden del Emperador, el que resulta más ceñido a los hechos y más popular. De él podríamos destacar el siguiente fragmento:

\footnotetext{
${ }^{3}$ La primera versión del Don Álvaro (1832), la de Tours, nunca representada y hasta hoy desconocida, fue escrita en prosa y sólo cuando el Duque de Rivas decidió escenificarla juzgó oportuno, según nos dice en el Prólogo, presentarla "con algunas variaciones esenciales y engalanada con varios trozos de poesía", lo cual viene a confirmar, entre otras cosas, la íntima conexión entre significado y significante. Frente a la visión unitaria del tema del destino, dominante en las primeras interpretaciones, los últimos estudios han tendido más a potenciar la expresividad del texto, la disposición escenográfica y la estructura musical. En este sentido, pueden verse los ensayos de Richard A. Cardwell, "Don Álvaro or the force of cosmic injustice", Studies in Romanticism 12, 1973, 559-567; Roberto G. Sánchez, "Cara y cruz de la teatralidad romántica (Don Álvaro y Don Juan Tenorio)", suplemento de Ínsula, no 336 (noviembre 1974); y L. Busquets, "Estructuras musicales del Don Álvaro", Revista de Literatura 102, 1989, 433-461.
} 


\author{
Grave el conde lo saluda \\ con una rodilla en tierra, \\ mas como grande del reino, \\ sin descubrir la cabeza. \\ El emperador, benigno, \\ que alce del suelo le ordena, \\ y la plática difícil \\ con sagacidad empieza. \\ $Y$ entre severo y afable, \\ al cabo le manifiesta \\ que es el que a Borbón aloje \\ voluntad suya resuelta. \\ Con respeto muy profundo, \\ pero con la voz entera, \\ respóndele Benavente \\ destocando la cabeza: \\ "Soy, señor, vuestro vasallo; \\ vos sois mi rey en la Tierra, \\ a vos ordenar os cumple \\ de mi vida y de mi hacienda.
}

\author{
"Vuestro soy, vuestra mi casa, \\ de mí disponed y de ella, \\ pero no toquéis mi honra \\ y respetad mi conciencia. \\ "Mi casa Borbón ocupe \\ puesto que es voluntad vuestra, \\ contamine sus paredes, \\ sus blasones envilezca; \\ "que a mí me sobra en Toledo \\ donde vivir sin que tenga \\ que rozarme con traidores, \\ cuyo solo aliento infecta, \\ "y en cuanto él deje mi casa, \\ antes de tornar yo a ella, \\ purificaré con fuego \\ sus paredes y sus puertas".
}

El diálogo del conde de Benavente con Carlos V es de gran intensidad dramática. Como en las comedias de villanos, el reconocimiento de la autoridad real ("Soy, señor, vuestro vasallo; / vos sois mi rey en la Tierra"), pues el rey gobierna en representación de Dios y es responsable de la armonía social, es lo que permite al conde defender su honra, vinculada a la vida misma. Lo que centra nuestra atención no es la benignidad del rey, que se supone de antemano, sino la dignidad humana del conde, su caracterización. La exaltación del protagonista, lograda por el contraste de la adversación ("mas como grande del reino", "pero con la voz entera", "pero no toquéis mi honra"); el uso del lenguaje apelativo, matizado por el vocativo ("Señor", "Vuestro soy") y los verbos en imperativo ("disponed", "respetad"), con el que se logra una mayor comunicación del lector; el predominio de la yuxtaposición, que descubre el triunfo de los elementos afectivos sobre los lógicos; y el símbolo transformador del fuego, que vuelve a restaurar el honor perdido, según se dice al final del romance ("En vano todo; tragóse / tantas riquezas el fuego, / a la lealtad castellana / levantando un monumento"), no hacen más que reforzar el sentido de la honra, que preside el fragmento y alcanza paradójicamente su dignificación en la voz del vasa1lo. Esta actitud de comprensión hacia lo que el otro representa ("Quedó absorto Carlos Quinto / de ver tan noble firmeza"), que corresponde al espíritu democratizador del romanticismo, es prueba de la exaltación del personaje, obtenida por vía de contraste, desde el punto de vista de la visualidad y la plástica escénicas. El grado de conciencia escenográfica que se aprecia en Don Álvaro, aunque sin la profusión de las 
acotaciones escénicas, se descubre también en los Romances históricos, que se reducen a una serie de estampas dramáticas 4 .

El Romanticismo, que recreó muchos de los temas heredados de la Ilustración, destacó el carácter popular y nacional de toda cultura. Para el Romanticismo, la cultura descansa en el lenguaje y cada lenguaje es la expresión del espíritu del pueblo (Volk geist). El Volk supone a la vez una religión, una nación, una cultura, una entidad social y política, articuladas lingüísticamente, pues la lengua funciona como espejo del alma del pueblo que la habla. El nacionalismo y el populismo románticos favorecieron el desarrollo del folklore y de géneros como la balada, el romance, la leyenda y el artículo de costumbres. En todos los países europeos se extendió el deseo de recopilar las canciones populares, habiéndose iniciado en Inglaterra durante el siglo XVIII. En España, las nuevas tendencias poéticas a partir de 1850, que acentúan el alejamiento de la oratoria para aproximarse al lirismo vivencial del cantar, no dejan de influir en la composición de la leyenda, género que, sin abandonar la religiosidad y tradición popular medievales, adquiere mayor complejidad debido a su extensión, a su fuerza expresiva y al contraste entre lo real y lo fantástico, cualidades visibles en las narraciones líricas de Zorrilla, máximo exponente de la leyenda romántica. Siguiendo su estela, Rivas publicó en 1854, bajo el título de Leyendas, una colección con tres grandes poemas narrativos: La azucena milagrosa, Maldonado y El aniversario. En la primera de ellas, escrita en Nápoles en diciembre de 1847 y dedicada a Zorrilla por haberle dedicado unos meses antes su leyenda La azucena silvestre, Rivas recoge el viejo tema del marido que mata a su mujer porque un rival desdeñado le convence de que es infiel. De las tres partes que la componen, la primera que empieza con la guerra de Granada y termina con la muerte de Blanca a manos de Nuño; la segunda, que narra la participación de Nuño en la conquista de México por Hernán Cortés, su regreso a Sevilla, el encuentro con la calavera de Rodrigo, que le descubre "el horrendo plan", y la confesión de su crimen a un monje, que resulta ser don García, el hermano de Blanca; y la tercera, que describe la larga penitencia de Nuño en las montañas de León, sus visiones infernales, la aparición de la "blanca cierva", que le guía hasta la imagen de la Virgen, y el hallazgo de la azucena en la tumba de Blanca, es esta última la que resalta por su trascendencia. De ella podríamos seleccionar el siguiente fragmento:

\footnotetext{
${ }^{4}$ A pesar de que los Romances históricos constituyen, para E.A. Peers, la mejor aportación de Rivas al romanticismo español y fue la obra más popular en su tiempo, no se le ha dedicado un trabajo de conjunto, salvo los estudios parciales de E. Gil y Carrasco (El Pensamiento, tomo I, $3^{\mathrm{a}}$ entrega, 1841); A. Dérozier, "Le Duc de Rivas et le résurgence du Romancero", Les Langues Néo-Latines 68, 1974, 24-50; Olga T. Impey, "Apuntes sobre el estilo romancístico del Duque de Rivas”, en VV. AA., Actes du XIII congrès international de linguistique et philologie romanes tenu à l'Université Laval, Vol.II, Québec (Université Laval) 1976, pp.895-904; David T. Gies, "El romance y el Romanticismo. Perspectivas de Agustín Durán", Dieciocho 3, 1980, 62-68; y J.L. Sánchez Fernández, La poesía épico-romántica del Duque de Rivas. Análisis de romances históricos y leyendas, Córdoba (Universidad) 1994.
} 
Vino, tras de hermoso día, una tarde deliciosa, en que de morado y rosa la atmósfera se vistió.

Y a la tumba cual solía, ya de aliento y vida escaso, con lento y con débil paso Nuño Garcerán llegó.

Cual nunca las florecillas y aquella abundante yerba, que el breve espacio conserva, lozanas juzgó encontrar.

$Y$ sobre ellas, de rodillas, en dulce y celeste calma, no con la voz, con el alma, comenzó, devoto, a orar.

El sol, desde el Occidente, entre nubes, de soslayo, moribundo metió un rayo hasta aquel sitio de paz,

como si del penitente despedirse pretendiera, y el último beso diera a su venerable faz.

A su luz roja, expirante, ve don Nuño un tallo hermoso del suelo brotar frondoso $y$ alzarse con rapidez, pues en brevísimo instante se desarrolla, florece, y una azucena aparece de celeste candidez.

La admira cual milagrosa y a un impulso soberano lleva la trémula mano y la arranca de raíz.

$Y$ con ella venturosa, dejando en el mismo punto en tierra el cuerpo difunto, voló a Dios su alma feliz.

Y aquella pura azucena fue la vencedora palma con que, engrandecida, el alma de Nuño en el cielo entró.

$Y$ de nuevas gracias llena aquella flor, desde el Cielo, a la Tierra en raudo vuelo un ángel restituyó.

Pues la hallaron colocada a la mañana siguiente, lozana, resplandeciente, consuelo de todo afán,

ante la imagen sagrada de la Virgen sin mancilla, en la rústica capilla que descubrió Garcerán.

La función del arte consiste en hacer de esto otra cosa. Metamorfosis, o formación de símbolos. En el texto literario, los significados literales resultan inseparables de los significados simbólicos. Lenguaje y naturaleza constituyen dos aspectos complementarios de una creación única, en la que el énfasis se pone en el proceso de dar forma, de expresar la naturaleza por medio de la imaginación. El lenguaje poético busca la transformación de lo cotidiano. En ese escenario natural ("en dulce y celeste calma"), donde el tiempo se suspende para comunicar la trascendencia, se sitúa el lenguaje religioso, que afirma una realidad más allá de la experiencia subjetiva del hablante y de la realidad objetiva del mundo. A través de los estudios sobre el origen del lenguaje, iniciados por los primeros románticos alemanes, se llegó a descubrir el simbolismo como principio creador de todo lenguaje religioso. Por eso aquí, los distintos símbolos, la tumba, el sol, el ángel, confluyen en el de la azucena, asociada a la palma como símbolo de la resurrección (“Y aquella pura azucena / fue la vencedora palma / con que, engrandecida, el alma / de Nuño en el cielo entró"), de manera que el símbolo, que se mueve de la separación a la reunión, se dirige a la restauración de la unidad primigenia que el hombre ha perdido a través de la reflexión. El significa- 
do de la realidad quedaría incompleto sin ese movimiento de ida y vuelta propio del símbolo, de ahí que al ascenso de la flor al cielo suceda su descenso a la tierra a través del ángel mediador ("Y de nuevas gracias llena / aquella flor, desde el Cielo, / a la tierra en raudo vuelo / un ángel restituyó"), ya que el objeto de la palabra poética es la totalidad misma, la unidad de la que se ha separado el presente. La relación con el ángel, símbolo de lo invisible y señor de lo indistinto, es una relación con lo sagrado, con su ausencia y su posible recuperación. Aún más importante que la realidad del símbolo es su intencionalidad trascendente. El Duque de Rivas era muy consciente de la trascendencia única de cada símbolo, por eso estructuró esta leyenda en torno al de la azucena, cuyo simbolismo lunar y femenino convierte a esta flor en realización de las posibilidades antitéticas del ser 5 .

Una trayectoria creadora no es posible sino como búsqueda artística y dialogía vital. La del Duque de Rivas, de formación neoclásica e ideología liberal, traduce, con su persistente ambigüedad, las contradicciones de la clase aristocrática a la que pertenece, el juego entre las apariencias y la realidad, que tiene su gestación en la ausencia de una burguesía verdaderamente revolucionaria. Tal vez esto explique lo efímero del movimiento romántico en España, tratándose más de una simple moda literaria que de una necesidad social. Al ser un movimiento puramente intelectual, pues la Constitución de 1812, hecha por intelectuales, no responde a las necesidades reales del pueblo español, de formación tradicional y en su mayor parte analfabeto, los liberales exiliados tendrán que aprender el Romanticismo en el extranjero. El exilio de Rivas, que marca la transición del neoclasicismo al romanticismo, según vemos en $E l$ Moro Expósito, y coincide con la etapa de su madurez literaria, al mostrar la separación radical entre artificio y realidad, de la que sería un buen ejemplo Don Álvaro, revela muy pronto su inautenticidad, la falta de correspondencia entre el pensamiento y la vivencia personal, y hasta qué punto el Romanticismo español fue un movimiento levantado sobre el vacío. Esta falta de conexión entre sentimiento y realidad, signo de la angustia sufrida durante su destierro, es lo que explica el abandono de su liberalismo juvenil y su evolución, tanto política como literaria, hacia una actitud más tradicionalista y conservadora. El paso de la exaltación juvenil a la madurez conservadora se debe, en gran medida, a la desilusión creada por la falta de realización de los ideales románticos durante el exilio. Este cambio de actitud, que comienza tras el regreso de su destierro en 1834, y alcanza su máximo esplendor con los numerosos cargos de los últimos años ("cargado de honores"), entre los que destacan los de Presidente de la Academia Española y del Consejo de Estado, puede seguirse a través de tres textos importantes: la comedia de magia El desengaño en un sueño (1842), su discurso a la Academia (1860) y su prólogo a La Familia de Alvareda (1861), de Fernán Caballero. En ellos, trasluce la nostalgia por un tiempo irremediablemente perdido ${ }^{6}$.

\footnotetext{
${ }^{5}$ Las leyendas del Duque de Rivas no han sido estudiadas con la misma amplitud que los Romances históricos, a pesar de su relación con las de Zorrilla. No hay, por tanto, estudios de conjunto, sino ensayos parciales, como el de Luis F. Díaz Larios, "De la épica a la leyenda romántica: Solimán y Zaida, de Ribot y Fonseré", Romanticismo, Génova, 3-4, 1988, 45-52. En cuanto a la asociación simbólica de la azucena con la palma, tengo en cuenta dos estudios: el de F. Jazmín, El lenguaje de las flores, Barcelona (Olañeta) 1980; y el de J. Daniélou, Los símbolos cristianos primitivos, Bilbao (Ed. Ega) 1993.

${ }^{6}$ Poca atención se ha prestado a los últimos años de la vida de Rivas, sobrte todo, los posteriores a 1834. Algunas referencias importantes pueden seguirse a través de su contemporáneo Nicomedes Pastor Díaz, "El Duque de Rivas (Ángel Saavedra)", en Galería de hombres célebres contemporáneos, tomo II, Madrid 1843, biografía compuesta a base de documentos y noticias facilitadas por el propio autor. En cuanto a su última etapa, de gran actividad política, podemos seguirla a través de algún artículo aislado, como los de G. Ribbans, "El regreso de Ángel Saavedra de su destierro en 1834”, Revista de Filología Española, 47, 1964, 421-427; S. Fernández Larraín, "Algo del Duque de Rivas a través de un epistolario. En el primer centenario
} 
En el primero de ellos, que sigue la línea alegórico-simbólica de Calderón, la sustitución de la rebeldía por la reflexión, por la aceptación filosófica de la vida del campo ("Al campo volviera, sí, / y a su tranquilo reposo", confiesa Lisardo en la escena II del Acto IV), revela un cambio de actitud, del tráfago social a la paz de la vida retirada, por parte de quien ha logrado instalarse en el moderantismo político-social. En el segundo, leído en la Academia con motivo de la recepción de don Cándido Nocedal, el 15 de mayo de 1860, al criticar la actitud social de la novela moderna "para esparcir dosctrinas disolventes, impías y corruptoras", echa de menos la reflexión del pasado sobre la urgencia social del presente: “ $¡ A$ h! yo quisiera también que volviesen también aquellos tiempos inocentes en que los altos problemas filosóficos, económicos, políticos y sociales eran exclusivamente patrimonio de las personas graves y sesudas que a ellos después de largas meditaciones y estudios se dedican". En el tercero, vuelve a añorar la desaparición de los valores tradicionales por la influencia de las novelas extranjeras: "El ilustrado autor de La Familia de Alvareda, viendo con dolor desparecer a toda prisa de nuestro suelo hasta la tradición del modo de ver, de sentir y de vivir de nuestros padres, y borrarse completamente la fisonomía característica de nuestra sociedad, y convencido de que nos causa tan trascendentales daños la influencia mortífera de las novelas extranjeras, únicos libros que por desgracia se leen hoy en España con avidez, ha querido valerse también de la novela, para intentar al menos ( y en sólo intentarlo hay gloria), luchar con la irrupción de ideas exóticas, que nos desnaturaliza y corrompe, y consignar las propiamente nacionales, que dominaban hace medio siglo, dando a nuestros padres tanta fuerza y tanta respetalidad". En los tres casos, lo que se echa de menos es un tiempo perdido en el ideal de la memoria. Al hacer una síntesis de la vida del Duque, afirma su amigo Juan Valera: "en el gran movimiento de renovación o revolución literaria que hubo en España de 1830 a 1850 es, tal vez, si no la principal, la más original figura". Y esta originalidad surge de su compromiso primario con la expresión artística, música interior resuelta en escritura, de su deseo de quedarse a solas con el lenguaje y eliminar de él toda pretensión de solemnidad, pues la reducción retórica, a la que él no fue ajeno, va en contra del ejercicio autoritario de la palabra.

de su muerte: 1865-1965”, Atenea 43, 1966, 124-249; y David J. Billick, "El duque de Rivas, teórico de la poesía romántica en España”, Ábside, México, 39, 1975, 451-470. 